Brit. J. prev. soc. Med. (1974), 28, 73-80

\title{
Twins and neural tube defects
}

\author{
E. G. KNOX \\ Department of Social Medicine, University of Birmingham
}

\section{SUMMARY}

The hypothesis that anencephalus stems from fetus-fetus interactions in dizygotic twin pairs is examined by comparing the epidemiological predictions of the hypothesis with available observations. The hypothesis itself was based upon the disease-discordance and sex-concordance characteristics of twin pairs affected with anencephalus, and upon the sex ratio of the disease itself. The testable predictions of the hypothesis are (a) that variations in the incidence of anencephalus should be related to variations in dizygotic twinning rates, and particularly that dizygotic twinning rates will set upper limits to the incidence of anencephalus, and (b) that the $F / M$ ratio in anencephalic infants will be high in circumstances of high incidence, and specifically when the incidence is high in relation to the dizygotic twinning rate. Examples from international comparisons, secular changes, social class gradients, and variations according to maternal age confirm a consistent correspondence between observations and these predictions. In addition, the possibility was tested that some fetus-fetus interactions might be based upon sequential rather than simultaneous pairs of fetuses. This model predicted asymmetries of sex ratio in sibs immediately preceding propositi, with differences according to the sex of the affected child, and the predicted findings were confirmed. The fetus-fetus interaction hypothesis is therefore extended in the terms that about one third of occurrences are determined in a sequential manner.

The success of the extended fetus-fetus interaction model in explaining a large number of otherwise unrelatable findings confirms its validity.

\section{INTRODUCTION}

It has been suggested that neural tube defects could arise on the basis of an interaction between twin fetuses (Knox, 1970). The balanced inhibition of invasion of maternal tissues by the trophoblast might operate less satisfactorily where two trophoblasts made contact and lead to an interaction where one fetus was destroyed and the other left with a neural tube defect.
The hypothesis was based chiefly on a contradiction between two observations: ( $a$ ) that affected twin pairs are usually discordant, and (b) that there is an excess of like-sexed pairs among these discordantly affected twins. This has been interpreted in the past simply as evidence of discordancy in monozygotic twins and as evidence of the importance of non-genetic factors. However, the direct evidence for discordant occurrences in monozygotic pairs depends mainly upon chorionic appearances and they are at best very rare (Stallybrass, 1960) while the fetus-fetus interaction offers a much more specific explanation. Just as singleton anencephalics were supposed to have arisen from twins, so discordant twins were supposed to have derived from initial triplets.

The normal maternal-fetal relationship is certainly complex, and many different model components can be postulated (with a family of possible aberations for each), but the one explored in greatest detail was a diallelic gene system situated on the X-chromosome. There would be three female genotypes (SS, ST, TT) and two male genotypes (SY, TY). The postulate was advanced that one twin may attack and destroy the other, when the attacker possesses a gene which the attacked fetus does not possess, but that the survivor is left with a defect. For example, in an ST/SY pair the female would destroy the male fetus and be left herself with a neural tube defect. These genetic contingencies were seen as a necessary, but not sufficient, condition for the production of anencephalus, and additional environmental factors were also supposed to exist. This particular model successfully predicted: (a) that there would be an excess of affected females compared with males, (b) that the recurrence rates in affected families would be at the frequencies actually observed, (c) that concordantly affected monozygotic twins would be excessively rare, (d) that discordantly affected twins (at term) would show an excess of like-sexed over unlike-sexed pairs, and $(e)$ that the incidence of neural tube defects would be higher in older mothers than in younger. 
Although the predictions were successful in qualitative terms, inaccuracies in the quantitative fitting of the available facts to the predictions of the model suggested a 'near miss' rather than an exact specification of the real process. The question arises whether these inaccuracies could be adequately met by proposing a multiallelic system, a combined autosomal and sex-linked system, or some similar modification of the fetus-fetus interaction model, or whether it is necessary to seek model mechanisms which, though analogous in a mathematical sense, are radically different in biological terms. Superfecundation, or complex sequential interactions between mother and fetuses rather than between fetus and fetus, are possible examples. Alternatively, there may be basic abnormalities in the division of sperm or egg precursors. However, the basic idea of a fetus-fetus interaction is not unique to this situation and remains attractive. Such interactions are responsible for conjoined twins and for certain kinds of teratoma and chimera; there is also some evidence (Campbell, 1961) that cardiac septal defects in singletons at term may sometimes arise from haemodynamic instabilities of the monochorionic circulations of first-trimester twins.

For these reasons it seemed profitable to develop in more detail those predictions of the model which might be checked against evidence, and to search for additional data not encountered at the time of the original analysis. This is the purpose of this paper.

The three main parameters of the model, operating in the population context, are the twin frequency, the gene frequencies, and the environmental trigger frequency. Predictions of the effects of variations of these parameters between different population groups, different times, and different places, depend upon the algebra of the model as laid out in the original presentation and upon some additional developments carried out since then. For present purposes the main testable predictions are $(a)$ that high dizygotic twinning rates would generally be associated with high anencephalus rates, and (b) that where high anencephalus rates can be attributed to high environmental trigger frequencies they should be associated with a relatively high female/ male ratio in affected infants.

\section{EFFECT OF TwIN Rates}

\section{INTERNATIONAL VARIATIONS}

A World Health Organisation study on the frequency of congenital malformations of different kinds (Stevenson, Johnston, Stewart, and Golding, 1966) examined occurrences in 24 different centres spread throughout the world. The frequencies of occurrence of anencephalus and of spina bifida were themselves highly correlated, and their joint incidence varied from $10 \cdot 3 / 1,000$ births in Belfast to less than $0 \cdot 6 / 1,000$ births in Calcutta and in Yugoslavia. The proportions of twin deliveries also varied substantially between centres, particularly for dizygotic pairs. They varied from $2 \cdot 73 / 1,000$ births in Manilla to $32 \cdot 2 / 1,000$ births in Alexandria.

The authors of the report noted an association between dizygotic twinning rates and the incidence of neural tube defects. For anencephalus and spina bifida together the correlation was $r=+0.578 \rightrightarrows$ $(P<0.01)$. They commented that the 'phenomenon ${ }_{\sigma}^{\omega}$ has not been demonstrated previously and it is $\bar{D}$ difficult to suggest any explanation except that in $\frac{\rho}{+}$ some way there are predisposing factors in common'. N There was no correlation between neural tube iv defects and monozygotic twinning rates.

The WHO study did not include any Japanese centres. Japan has a low dizygotic twinning rate (James, 1972), in the range $2 \cdot 0-2 \cdot 4 / 1,000$ births, $\vec{z}$ compared with values mainly in the range $7 \cdot 0$ - 产 $9 \cdot 6 / 1,000$ births in most European countries. Japan also has a low anencephalus rate. Neel (1958) counted 34 anencephalics among 63,796 births Hiroshima, Nagasaki, and Kure, an incidence $0 \cdot 5 / 1,000$ births.

The Republic of Ireland was not represented in the WHO study although it has one of the highest anencephalus rates in the world. Dean and Keane $\stackrel{\mathbb{\Omega}}{\square}$ (1972) have recently commented upon the high $\overrightarrow{\overrightarrow{0}}$ twinning rate in the Republic of Ireland, for example 3 $15 \cdot 1 / 1,000$ births in 1959 and $13 \cdot 6 / 1,000$ births in 1968 compared with $10 \cdot 0 / 1,000$ births in 1968 in England and Wales. About $74 \%$ of the twin births in the Republic of Ireland (1969-70) were dizygotic. $\frac{\rho}{?}$

There are known exceptions to the positive association between twinning and anencephalus rates. For example, the dizygotic twinning rate $ᄋ$ among the Yoruba of Western Nigeria is probably the highest in the world (Knox and Morley, 1960)을 yet anencephalus seems to be very rare here. In the terms of the model, however, the twinning rate을. sets only the upper limits of anencephalus rates. $\bar{N}$ Appropriate gene frequencies, or the absence of the . necessary environmental trigger, could ensure that $\tilde{O}$ fetus-fetus interaction was rare even in the presence $N$ of a high twinning rate. No examples have beeno discovered of the reverse association, that is a lowe dizygotic twinning rate in the presence of a high anencephalus rate.

\section{Secular Changes}

James (1972) has drawn attention to a decline in the dizygotic twinning rates in many countries of 
the world. In England and Wales the fall began about 1956 at levels around $9 \cdot 1 / 1,000$ births, and the figure had declined to around $7 \cdot 0 / 1,000$ births in 1968. The fall has continued since then and the 1971 figures for England and Wales indicate a dizygotic twinning rate of $6 \cdot 3 / 1,000$ births. The changes were even more marked in Scotland and are detectable in Italy, Norway, Holland, Australia, Denmark, New Zealand, Sweden, Belgium, Switzerland, Portugal, Spain, the United States (where the decline began earlier), and even in Japan where the dizygotic twinning rate was already low. This finding has recently been confirmed in Canada (Elwood, 1973). Only a part of these changes is attributable to shifts in the maternal age/birth-rank distributions of all births and the main reasons for the decline in twinning rates have not yet been identified. However, anencephalus rates have also fallen in many places over the same period of time. In England and Wales the rate fell from 2.05/1,000 births in 1961 to $1 \cdot 59 / 1,000$ births in 1971. Parallel secular trends never form a firm argument in themselves but in this case they add one more element of confirmation to the postulated relationship between twinning and neural tube defects.

\section{Pharmacological Effects}

Effective treatments for anovular infertility in recent years, particularly the use of clomiphene, have encountered a problem in the form of a high incidence of multiple pregnancy. Until recently this was the only known complication of clomiphene treatment. Recently, however, the occurrence of malformations has been reported (Dyson and Kohler, 1973; Sandler, 1973). Other authors (for example, Whitelaw, Kalman, and Grams, 1970) noted substantial abortion rates following conception while on this drug, and have commented that the induced ovulation rate is considerably higher than the induced pregnancy rate. It is impossible on present evidence to say whether the malformation rate is greater than would have been expected, but the three specific cases of malformation reported to date were all anencephalic.

\section{EfFects of EnVIronment and Gene Frequency VARIATIONS}

There is no reason, under the terms of the hypothesis, why variations in anencephalus rate secondary to variations in the dizygotic twin rate, should be accompanied by changes in the $F / M$ ratio of anencephalics, but, as was shown in the original presentation of the hypothesis, changes in the strength of environmental factors might be so accompanied. Provided that the trigger frequencies operated equally in the two directions (S presence attacking $S$ absence and $T$ presence attacking $T$ absence), variations in gene frequency would not be accompanied by variations in sex ratio.

The possibility that the trigger effects could be asymmetrical, operating more strongly for the S-gene than for the T-gene, for example, was not considered in the original paper, but it has since been explored further. A series of computations was made for a series of independently varying S-trigger and T-trigger frequencies and for a series of $S$ and $T$ gene frequencies. It was found in fact that asymmetric trigger frequencies were indeed capable of inducing changes in the $F / M$ ratio but, in general, these changes were small. For example, in one particular combination a five-fold movement of gene frequency shifted the $F / M$ ratio only from 2.58 to $2 \cdot 48$. On the other hand, the response to variations in the environmental trigger probabilities was substantial and the $F / M$ ratio could be shifted between about 2.0 and 3.7 in response to such manipulation.

Therefore, in situations where comparisons between different groups or times or places do not cross the boundaries of gross genetic inhomogeneities, and are not marked by differences in twinning rates, we can take a joint variation of $F / M$ ratio and incidence as a confirmation of the hypothesis. Where there is a presumption of a genetic difference, as in international studies, or of twinning rate differences, as in variations according to maternal age, the interpretation of incidence and sex ratio patterns will be more complex.

\section{Social Class}

It has been shown in several sets of data, including Scottish data, that the incidence of anencephalus is several times higher in social class $\mathrm{V}$ than in social class I, with a steady gradient between. Dizygotic twinning rates do not vary substantially between the social classes, and we may assume that the differences in incidence are caused by environmental factors rather than by gene frequency variations. Table I sets out the number of male and female

TABLE I

INCIDENCE AND SEX RATIO OF ANENCEPHALUS BY SOCIAL CLASS, SCOTLAND 1960-69

\begin{tabular}{|c|c|c|c|c|c|c|c|}
\hline \multicolumn{3}{|c|}{ Social Class } & I & II & III & IV & $\mathbf{V}$ \\
\hline $\begin{array}{l}\text { No. of males } \\
\text { No. of females }\end{array}$ & $\ddot{*}$ & $\ddot{x}$ & $\begin{array}{l}16 \\
37\end{array}$ & $\begin{array}{l}40 \\
91\end{array}$ & $\begin{array}{l}343 \\
899\end{array}$ & $\begin{array}{l}105 \\
351\end{array}$ & $\begin{array}{r}87 \\
276\end{array}$ \\
\hline $\begin{array}{l}\text { Incidence/1,000 } \\
\mathrm{F} / \mathrm{M} \text { ratios }\end{array}$ & & .. & & & $\begin{array}{l}2 \cdot 32 \\
2 \cdot 62\end{array}$ & 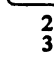 & $\begin{array}{l}71 \\
27\end{array}$ \\
\hline
\end{tabular}


anencephalics born in Scotland over a 10-year period, together with incidence and sex ratios. The rise of $F / M$ ratio from $2 \cdot 29$ in social classes $I$ and II to $3 \cdot 27$ in social classes IV and V is almost exactly as predicted by the model.

\section{INTERNATIONAL DifFERENCES}

In the WHO international study already referred to, one source of variation of incidence was related to the dizygotic twinning rate. In addition, there were concomitant sex ratio and incidence variations suggesting additional environmental and/or genetic differences between centres. Ten of the 24 centres had incidences of neural tube defects greater than the mean for the full set of data and Table II compares these centres with the remaining centres with

TABLE II

NEURAL TUBE DEFECTS: INTERNATIONAL COMPARISONS OF SEX RATIOS ACCORDING TO INCIDENCE

\begin{tabular}{|c|c|c|}
\hline & $\begin{array}{l}\text { Centres* with Incidence } \\
\text { greater than Overall } \\
\text { Mean } \\
\text { (10 centres) }\end{array}$ & $\begin{array}{c}\text { Centres* with Incidence } \\
\text { less than Overall } \\
\text { Mean } \\
\text { (14 centres) }\end{array}$ \\
\hline $\begin{array}{l}\text { Affected } \mathbf{M} \\
\text { Affected } \mathbf{F} \\
\mathbf{F} / \mathbf{M} \text { ratio }\end{array}$ & $\begin{array}{r}281 \\
405 \\
1 \cdot 44\end{array}$ & $\begin{array}{l}188 \\
201 \\
1 \cdot 07\end{array}$ \\
\hline
\end{tabular}

*As in Stevenson et al. (1966)

respect to the sex ratios of the malformed infants. This shows that the centres with the higher incidences had significantly higher $F / M$ ratios than did the other centres. These data refer to neural tube defects as a whole, not simply anencephalus, so the general range of $F / M$ ratios differs from the Scottish and English anencephalic stillbirths data. However, in qualitative terms, the finding is again in accord with the predictions of the model.

The examination can be sharpened by standardizing the high and low incidence areas according to the background dizygotic twinning rates. Table III

TABle III

NEURAL TUBE DEFECTS: INTERNATIONAL NEURARISONS OF SEX RATIOS ACCORDING TOMPARISONS OF SEX RATIOS ACCORDING RATE

\begin{tabular}{|c|c|c|}
\hline & \multicolumn{2}{|c|}{ Ratio of Incidence to Dizygotic Twinning Rate } \\
\hline & $\begin{array}{l}\text { High Ratios } \\
\text { ( } 4 \text { centres*) }\end{array}$ & $\begin{array}{l}\text { Low Ratios } \\
\text { (18 centres*) }\end{array}$ \\
\hline $\begin{array}{l}\text { Affected } \mathbf{M} \\
\text { Affected } \mathbf{F} \\
\mathbf{F} / \mathbf{M} \text { ratio }\end{array}$ & $\begin{array}{r}185 \\
297 \\
1 \cdot 61\end{array}$ & $\begin{array}{c}266 \\
289 \\
1 \cdot 09\end{array}$ \\
\hline
\end{tabular}

* As in Stevenson et al. (1966).

Discrepancies of totals between this and Table II occur because two centres failed to give dizygotic twinning rates. compares those centres with the highest anen- $\frac{\cap}{3}$ cephalus/twin ratios with the remaining centres. $\stackrel{\Phi}{\circ}$ The difference in $\mathrm{F} / \mathrm{M}$ ratio is more marked than for the unstandardized comparison. It suggests that the $\overrightarrow{\vec{F}}$ twin effect and the environmental effect are independent.

\section{Seasonal Variations}

Seasonal variations in anencephalic births have been observed many times but their interpretation ${ }^{\text {s }}$ is difficult (Leck and Record, 1966). We may. assume that there is no seasonal variation in gene $\overrightarrow{\vec{H}}$ frequencies, and in most communities there is no. evidence of seasonal variation in dizygotic twinning rates. Therefore, the variation must be due to? environmental factors. In addition, we know that the environmental factors have irregular distribu-i tions in that seasonal variation, while observed $\omega$ repeatedly in the United Kingdom, is not generallyo observed in the United States and apparently. varies in its amplitude at different times in thez United Kingdom. However, there is little to help use distinguish between the possibilities that the seasonal variation in abnormal births reflects seasonal variation in initial developmental failues or a seasonal variation in the survival to term abnormal fetuses.

Numbers of anencephalic births according to the month of the year have been provided by the Regis $\frac{0}{8}$ trar General for Scotland, separately for males and females, since 1961. Data for 10 years are presented $\vec{b}$ in Table IV. The highest $F / M$ ratio was in April and various alternative quarterly groupings gave higher $\mathrm{F} / \mathrm{M}$ ratios in the spring than in other quarters of the year. This corresponds with the traditionalo period of highest incidence. However, the $F / M$ ratio by month fluctuated irregularly, and in recen $\bar{T}$ years the seasonal variation in Scotland seems to have disappeared so that an unequivocal interpre tation of these data does not seem possible.

\section{Maternal Age}

The incidence of neural tube defects rises with? increasing maternal age. For spina bifida thळ్ relationship is simply linear but for anencephalus alone there is a secondary excess in younger mother\& and the distribution is U-shaped (Edwards, 1958) An interpretation based on the fetus-fetus interaction model would attribute the general rise at highes maternal ages to the rise in the frequency of dizygoti twinning. The different curves for anencephalus and spina bifida, and the excess of anencephalus in the younger mothers, would be attributed to a supert imposed environmental factor operating morf strongly at earlier ages. The model therefore does 
TABLE IV

INCIDENCE AND SEX RATIOS OF ANENCEPHALUS BY MONTH OF BIRTH, SCOTLAND 1961-69

\begin{tabular}{|c|c|c|c|c|c|c|c|c|c|c|c|c|c|c|}
\hline & & \multicolumn{12}{|c|}{ Month } & \multirow[b]{2}{*}{ Total } \\
\hline & & 1 & 2 & 3 & 4 & 5 & 6 & 7 & 8 & 9 & 10 & 11 & 12 & \\
\hline $\begin{array}{l}\text { Affected males } \\
\text { Affected females } \\
\text { Incidence/ } 1,000 \text { births } \\
\text { F/M ratio by month }\end{array}$ & $\begin{array}{l}\cdots \\
\cdots \\
\cdots\end{array}$ & $\begin{array}{r}61 \\
176 \\
3 \cdot 00 \\
2 \cdot 88\end{array}$ & $\begin{array}{r}58 \\
154 \\
2 \cdot 97 \\
2 \cdot 66\end{array}$ & $\begin{array}{r}40 \\
128 \\
2 \cdot 07 \\
3 \cdot 20\end{array}$ & $\begin{array}{r}43 \\
149 \\
2 \cdot 52 \\
3 \cdot 47\end{array}$ & $\begin{array}{r}52 \\
134 \\
2 \cdot 34 \\
2 \cdot 58\end{array}$ & $\begin{array}{r}46 \\
144 \\
2 \cdot 52 \\
3 \cdot 13\end{array}$ & $\begin{array}{r}59 \\
154 \\
2 \cdot 76 \\
2 \cdot 61\end{array}$ & $\begin{array}{r}62 \\
152 \\
2 \cdot 82 \\
2 \cdot 45\end{array}$ & $\begin{array}{l}52 \\
136 \\
2 \cdot 62 \\
2 \cdot 61\end{array}$ & \multirow[t]{2}{*}{$\begin{array}{r}54 \\
152 \\
2 \cdot 63 \\
2 \cdot 81 \\
\end{array}$} & $\begin{array}{r}55 \\
154 \\
3 \cdot 05 \\
2 \cdot 80\end{array}$ & $\begin{array}{r}44 \\
126 \\
2 \cdot 34 \\
2 \cdot 86\end{array}$ & \multirow[t]{2}{*}{$\begin{array}{r}626 \\
1,759 \\
2 \cdot 63 \\
2 \cdot 81\end{array}$} \\
\hline $\mathbf{F} / \mathbf{M}$ ratio by quarters & . & \multicolumn{3}{|c|}{$2 \cdot 88$} & \multicolumn{3}{|c|}{3.03} & \multicolumn{3}{|c|}{$2 \cdot 56$} & & \multicolumn{2}{|l|}{$2 \cdot 82$} & \\
\hline
\end{tabular}

not predict a simple relationship between high incidence and high $\mathrm{F} / \mathrm{M}$ ratio, but rather an increasing $\mathrm{F} / \mathrm{M}$ ratio where the incidence is high in relation to the dizygotic twinning rate, that is, in young women.

Data from the reports of the Registrar General for England and Wales between 1961 and 1970 are given in Table $\mathrm{V}$ where the incidence of anencephalus, the F/M ratio for anencephalus, and the

\section{TABLE V}

ANENCEPHALUS IN MALES AND FEMALES ACCORDING TO MATERNAL AGE, ENGLAND AND WALES 1961-70

\begin{tabular}{|c|c|c|c|c|c|c|}
\hline & \multicolumn{6}{|c|}{ Maternal Age (years) } \\
\hline & -19 & -24 & -29 & -34 & -39 & $40+$ \\
\hline 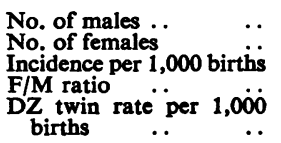 & $\begin{array}{r}436 \\
1,187 \\
2 \cdot 07 \\
2 \cdot 72 \\
3 \cdot 00\end{array}$ & $\begin{array}{l}1,366 \\
3,487 \\
1 \cdot 72 \\
2 \cdot 55 \\
5 \cdot 30\end{array}$ & $\begin{array}{l}1,094 \\
2,710 \\
1 \cdot 49 \\
2 \cdot 48 \\
7 \cdot 60\end{array}$ & $\begin{array}{r}643 \\
1,546 \\
1 \cdot 55 \\
2 \cdot 40 \\
10 \cdot 80\end{array}$ & $\begin{array}{r}375 \\
899 \\
1 \cdot 87 \\
2 \cdot 40 \\
13 \cdot 00\end{array}$ & $\begin{array}{r}119 \\
270 \\
1 \cdot 86 \\
2 \cdot 27 \\
8 \cdot 20\end{array}$ \\
\hline
\end{tabular}

dizygotic twinning rates can be compared. The $F / M$ ratio increases systematically from older to younger women, parallel with the increasing ratio of anencephalus incidence to dizygotic twinning rate. A similar pattern is seen in Scotland, as shown in Table VI.

TABLE VI

ANENCEPHALUS IN MALES AND FEMALES ACCORDING TO MATERNAL AGE, SCOTLAND 1960-69

\begin{tabular}{|c|c|c|c|c|c|c|}
\hline & \multicolumn{6}{|c|}{ Maternal Age (years) } \\
\hline & -19 & -24 & -29 & -34 & -39 & $40+$ \\
\hline 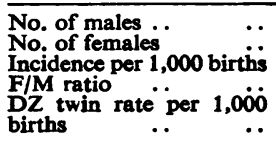 & $\begin{array}{r}58 \\
188 \\
3.02 \\
3.24 \\
2.80\end{array}$ & $\begin{array}{r}216 \\
634 \\
2 \cdot 63 \\
2 \cdot 94 \\
5 \cdot 60\end{array}$ & $\begin{array}{r}202 \\
532 \\
2 \cdot 38 \\
2 \cdot 63 \\
7 \cdot 70\end{array}$ & $\begin{array}{r}137 \\
348 \\
2 \cdot 69 \\
2 \cdot 54 \\
11 \cdot 10\end{array}$ & $\begin{array}{r}79 \\
202 \\
3.09 \\
2.56 \\
14 \cdot 20\end{array}$ & $\begin{array}{r}19 \\
71 \\
3 \cdot 38 \\
3 \cdot 74 \\
8 \cdot 20\end{array}$ \\
\hline
\end{tabular}

\section{Sequential Fetus-Fetus Relationships}

An alternative circumstance in which a fetus-fetus interaction could occur would be if trophoblast or other tissue from an earlier fetus persisted until the next conception had occurred. One example of tissue persistence is already known, namely the survival of transplacentally transfused fetal red cells. In the presence of appropriate fetal-maternalfetal blood group sequences, it has been shown that relatively short intervals between pregnancies are followed by an increased risk of rhesus immunization (Knox, 1968). If sequential fetus-fetus interactions were a basis for anencephalus we might expect to find two effects.

First, by analogy with rhesus haemolytic disease, we might expect to find a relatively short interval since the previous pregnancy in women who had affected infants. Data on fallow periods preceding anencephalic and spina bifida children were published many years ago by Record and McKeown, (1950). With both malformations the mean preceding pregnancy interval was less than for controls.

Second, because it is postulated that the anencephalic interaction is based upon sex-linked markers we would expect asymmetries of sex ratio in pregnancies immediately preceding affected children, and the asymmetries should be different according to whether the abnormal fetus is male or female.

The nature of the expected sex asymmetries is demonstrated in Table VII where interacting genotype pairs are displayed, together with their relative population frequencies (Knox, 1970). These pair-frequencies were derived originally for dizygotic twin pairs of 15 possible kinds, but only the type numbers shown in the Table are capable of eliciting interactions, and this is equally true for sequential sib-pairs. The relative frequencies supplied in the table are a simplification of the absolute frequencies computed in the original pair-type analysis, these frequencies being divided by $s(1-s) / 4$. Thus, the absolute frequency of pair type 9, among all pairs, is $s^{2}(1-s) / 4$. 
TABLE VII

EXPECTED SEX RATIOS IN PREGNANCIES PRECEDING AN ANENCEPHALIC

\begin{tabular}{|c|c|c|c|c|c|c|c|}
\hline \multicolumn{4}{|c|}{ Sib Pair Type } & \multicolumn{4}{|c|}{ Relative Frequencies of Sequential Interaction Types } \\
\hline \multicolumn{2}{|c|}{ Type No. } & \multirow[b]{2}{*}{$\begin{array}{c}\text { Genotype } \\
\text { TY/SS } \\
\text { TT/SY } \\
\text { TY/SY } \\
\text { SS/ST } \\
\text { TT/ST } \\
\text { SY/ST } \\
\text { TY/ST }\end{array}$} & \multirow{2}{*}{$\begin{array}{c}\begin{array}{c}\text { Relative } \\
\text { Frequency }\end{array} \\
s^{*} \\
(1-s) \\
1 \\
s \\
(1-s) \\
(1+2 s) \\
(3+2 s)\end{array}$} & \multirow[b]{2}{*}{$\begin{array}{c}\text { Male on Female } \\
\begin{array}{c}\mathrm{s} \\
\text { (1-s) } \\
= \\
=\end{array}\end{array}$} & \multirow[b]{2}{*}{$\begin{array}{c}\text { Male on Male } \\
\frac{\overline{2}}{=} \\
=\end{array}$} & \multirow[b]{2}{*}{$\begin{array}{c}\text { Female on Female } \\
\qquad \begin{array}{c}\overline{-} \\
(1-s) \\
=\end{array}\end{array}$} & \multirow[b]{2}{*}{$\begin{array}{c}\text { Female on Male } \\
\begin{array}{c}(1-s) \\
\bar{z} \\
(1 \overline{+2 s}) \\
(3+2 s)\end{array}\end{array}$} \\
\hline $\begin{array}{r}9 . . \\
10 . \\
11 \ldots \\
12 . \\
13 \ldots \\
14 \ldots \\
15 . .\end{array}$ & $\begin{array}{c}\because \\
\because \\
\because \\
\because \\
\cdots\end{array}$ & & & & & & \\
\hline $9-15$ & & & & 1 & 2 & 1 & $5+4 s$ \\
\hline
\end{tabular}

$M / F$ ratio preceding a male propositus $[(M$ on $M) /(M$ on $F)]=2: 1$

$M / F$ ratio preceding a female propositus $[(F$ on $M) /(F$ on $F)]=(5+4 s) / 1=5: 1$ to $9: 1$

* $s$ = gene frequency of gene $S:(1-s)=$ gene frequency of gene $T$.

Sib pair types, type numbers, and frequencies taken from Knox (1970).

Table VII also attributes the relative liabilities of each pair-type to each of the interaction types (male on female, male on male, female on female, female on male) to which it is susceptible. Types 9-11 are subject to interactions in either direction, types 12-15 only in one direction. The columns of the table are totalled as if they did not interact with each other in any way, and as if no asymmetric function had to be introduced for possible S-trigger and T-trigger differences. The result is an expectation of a $M / F$ ratio in sibs preceding a male propositus of about $2: 1$, and preceding a female propositus between $5: 1$ and $9: 1$, depending upon the gene frequency.

If interaction between columns did occur-that is, for example, a type 9 pair cannot in fact operate in both directions simultaneously and has to 'choose' one or the other, giving $s / 2$ instead of $s$ for the interaction frequencies-then the results might be affected. This applies in types 9-11 which can operate in both directions, and might operate at high trigger frequencies. However, provided that they do not interact mutually and disappear from the scene altogether, the effect upon the total is quite small; in fact the ratio preceding a male remains at $2: 1$ and the values preceding a female propositus change only marginally.

If the symmetry assumption is breached the situation is again complicated, and the ratio preceding a male propositus as well as that preceding a female propositus becomes dependent upon gene frequencies. However, in every case examined the $\mathbf{M} / \mathbf{F}$ ratios of sibs preceding an affected female were three to six times those preceding an affected male. In children following an affected child, or in earlier children other than the immediately preceding child, the model offers no basis for expectations other than a $1: 1$ sex ratio.
No published data have been found on which the $\mathrm{O}$ sex ratio asymmetry predictions might be tested. However, the sibship data on which Record and 3 McKeown based their studies still exist and were made available for analysis. Table VIII displays $\vec{\varphi}$ the sex distributions of immediately preceding sibs of other preceding sibs, and of later sibs of sping bifida infants and anencephalic infants, separater for each sex. The immediately preceding sibs of affected female infants show a considerable excess of males. The finding is repeated, less strongly in $\frac{\square}{D}$ the immediately preceding sibs of affected males. $\square$ By contrast, earlier sibs than immediately preceding $\overrightarrow{\overrightarrow{0}}$ sibs, and later sibs, have symmetrical sex ratios. 3 Having regard to the algebraic ratios computed in Table VII, and making plausible assumptions concerning gene frequencies, these asymmetries $\bar{\Phi}$ suggest that one quarter to one third of anen-? cephalus and spina bifida occurrences at birth $\frac{5}{3}$ ranks 2 or higher depend upon sequential interactions between successive full-term sibs while theo

TABLE VIII

SEX RATIOS IN SIBSHIPS OF INFANTS WITH ANENCEPHALUS OR SPINA BIFIDA

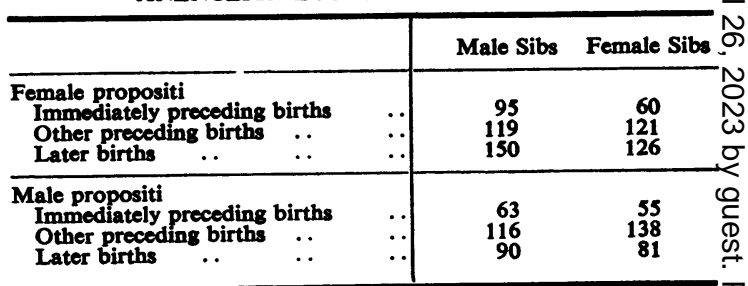

Sib dath are based upon 134 male and 168 female spina bifida and 90 male and 209 female anencephalus. These data relate to materiaf described by Record and McKeown (1950) but exclude sibships withD preceding twins and include some outside the geographical and time preceding twins and include some outside the geographical and the published data. Differing row proportions for malesD and females arise because of the different sex and birth rank distribu tions of spina bifida and anencephalus. 
remaining two thirds to three quarters depend upon simultaneous interactions. Residual abortus tissues could also operate in this way and for the purposes of this calculation would be included within the 'simultaneous interaction' group, while the remainder would consist of twins; in fact 48 of the 601 affected infants used in this analysis were immediately preceded by a miscarriage.

\section{Discussion}

It is not necessary to invoke the model of an environmentally triggered fetus-fetus interaction to explain any single feature of the epidemiology of anencephalus. The chief virtue of the hypothesis is its power to explain a range of curious and disparate factors with great economy. In addition to the initial facts upon which its formulation depended, notably the asymmetric sex ratio of the disease, and the sex- and disease-concordance phenomena in affected twin pairs, it has been shown now that its predictions in two other respects are confirmed. First, it is confirmed that there is a general association between dizygotic twin incidences and anencephalus rates and that the occasional known exceptions to the association are not in a direction which would be fatal to the hypothesis. Second, it is shown that where variations in incidence are not attributable to twinning rate variations or are superimposed upon them, and especially where the variations can be attributed specifically to environmental determinants, then the $F / M$ ratio of affected infants varies systematically with the strength of the environmental factor. This effect is not in all cases a simple relationship between $F / M$ ratio and incidence, and the maternal age effect provides fairly specific support for the fetus-fetus interaction model.

The determinants of changing twinning rates are also presumably environmental and they are likely to be different from those determining the proportion of twin fetuses which result in anencephalic births. Both sets of causes will need to be examined independently. In the meantime we must take account of falling dizygotic twinning rates when searching for secular and seasonal associations between the incidence of anencephalus and suspect environmental factors. For example, a study by Knox (1972) of seasonal, secular, and irregular correspondences between dietary intakes and the subsequent incidence of anencephalus might have produced different results if the incidence figures had been expressed in relation to the dizygotic twinning rates. This study suggested that, among other suspect foods, meat cured in the presence of nitrites may contain toxic substances capable of acting as the trigger. The least satisfactory component of the correspondence lay in the secular element, and correction of incidence in relation to the changing dizygotic twinning rates of the period examined would in this case have improved the fit.

The possibility of sequential as opposed to simultaneous fetus-fetus interactions was contemplated initially as a potential disproof of the model. The predictions arising from a sequential interaction hypothesis were highly specific and in the event the available evidence supplied a convincing qualitative match for the predictions. The results suggest that about one third of all interactions may be determined in this way. It will of course be important to seek additional data on this point. In the meantime, this finding amplifies the conclusion already reached that the twin-based model cannot be a sole explanation of the facts, at the same time strengthening the more general hypothesis of the fetus-fetus interaction. Many of the quantitative strains between predictions and facts encountered when the twin model was originally proposed are relieved by the supposition that the interaction can occur either on a simultaneous or upon a sequential basis. In its more developed form the model provides so comprehensive an explanation of otherwise unrelatable facts that its general validity can now scarcely be doubted.

No doubt the details will be resolved with greater clarity as study proceeds. There are immediate questions concerning the effects of abortions, the role of the mother as an intermediary between the two fetuses, the exact genetic cellular and chemical mechanisms, and the part played by external environmental factors. However, these elements can now be regarded as subsets of a process whose principal components are reasonably clear.

\section{REFERENCES}

Campbell, M. (1961). Twins and congenital heart disease. Acta Genet. med. (Roma), 10, 443.

Dean, G. and Keane, T. (1972). An investigation of the high twinning rate in the Republic of Ireland. Brit. $J$. prev. soc. Med., 26, 186.

Dyson, J. L. and KoHLER, H. G. (1973). Anencephaly and ovulation stimulation. Lancet, 1, 1256.

EDWARDS, J. H. (1958). Congenital malformations of the central nervous system in Scotland. Brit. J. prev. soc. Med., 12, 115.

Elwood, J. M. (1973). Changes in the twinning rate in Canada 1926-70. Brit. J. prev. soc. Med., 27, 236.

JAMES, W. H. (1972). Secular changes in dizygotic twinning rates. J. biosoc. Sci., 4, 427. 
KNox, E. G. (1968). Obstetric determinants of rhesus sensitization. Lancet, 1, 433.

(1970). Fetus-fetus interaction-a model aetiology for anencephalus. Develop. Med. Child Neurol., 12, 167.

(1972). Anencephalus and dietary intakes. Brit. $J$. prev. soc. Med., 26, 219.

and Morley, D. (1960). Twinning in Yoruba women. J. Obstet. Gynaec. Brit. Emp., 67, 981.

LECK, I. and Record, R. G. (1966). Seasonal incidence of anencephalus. Brit. J. prev. soc. Med., 20, 67.

NeEL, J. V. (1958). A study of major congenital defects in Japanese infants. Amer. J. hum. Genet., 10, 398.
ReCORD, R. G. and McKeown, T. (1950). Congenital malformations of the central nervous system. Maternal reproductive history and familial incidence. Brit. $J$. soc. Med., 4, 26.

SANDLER, B. (1973). Anencephaly and ovulation stimulation. Lancet, 2, 379.

Stallybrass, F. C. (1960). Anencephaly in uniovular twins: Report of a case. Brit. J. prev. soc. Med., 14, 136.

Stevenson, A. C., Johnston, H. A., Stewart, M. I. P., and GoldING, D. R. (1966). Congenital malformations. Bull. Wld Hlth Org. Suppl. 34.

Whitelaw, M. J., Kalman, C. F., and Grams, L. R. (1970). The significance of the high ovulation rate versus the low pregnancy rate with clomid. Amer. J. Obstet. Gynaec., 107, 865. 